\title{
Identification of Science Learning Difficulties During the Covid-19 Pandemic in Class V SDN Peterongan
}

\author{
Arfanny Hanum \\ SDN Peterongan \\ arfannyzz@gmail.com
}

\section{Article History}

received $3 / 12 / 2020$

\begin{abstract}
This study aims to identify problems in learning science at home during the Covid-19 pandemic that occurred in fifth grade students at SDN Peterongan in the 2019/2020 school year. The method used in this research is descriptive qualitative with a phenomenological approach. The data sources of this study were all fifth grade students, parents, and fifth grade teachers. The data collection technique was done by using questionnaires, interviews, and documentation studies. The data validity test used in this study was technical triangulation and source triangulation. Data were analyzed using the data analysis model Miles and Huberman. The results of this study indicate that student learning problems occur due to lack of interest and motivation of students and students have difficulty understanding concepts. Only $36 \%$ of students showed interest in online science learning, and $70 \%$ of students had difficulty understanding concepts. The problems that occur are caused by several factors. Based on these factors, efforts that can be made to solve learning problems experienced by students are to increase students' interest and motivation by choosing learning methods and media that make students interested and become more active, provide enrichment and remedial, and maintain communication with parents to monitor student learning difficulties at home.
\end{abstract}

Keywords: science, learning problem, elementary school

\begin{abstract}
Abstrak
Penelitian ini bertujuan untuk mengidentifikasi permasalahan dalam pembelajaran IPA di rumah pada masa pandemi Covid-19 yang terjadi pada peserta didk kelas V SDN Peterongan tahun pelajaran 2019/2020. Metode yang digunakan dalam penelitian ini adalah deskriptif kualitatif dengan pendekatan fenomenologis. Sumber data penelitian ini adalah seluruh peserta didik kelas $\mathrm{V}$, orang tua, dan guru kelas $\mathrm{V}$. Teknik pengumpulan data dilakukan dengan menggunakan kuesioner, wawancara, dan studi dokumentasi. Uji validitas data yang digunakan dalam penelitian ini adalah triangulasi teknis dan triangulasi sumber. Analisis data menggunakan model analisis data Miles dan Huberman. Hasil penelitian ini menunjukkan bahwa masalah belajar peserta didik terjadi karena kurangnya minat dan motivasi dan mengalami kesulitan memahami konsep. Hanya $36 \%$ peserta didik yang menunjukkan minatnya dalam pembelajaran IPA secara daring, dan $70 \%$ peserta didik mengalami kesulitan memahami konsep. Permasalahan yang terjadi disebabkan oleh beberapa faktor. Berdasarkan faktor-faktor tersebut, upaya yang dapat dilakukan untuk memecahkan masalah belajar yang dialami peserta didik adalah dengan meningkatkan minat dan motivasi dengan memilih metode dan media pembelajaran yang membuat peserta didik tertarik dan menjadi lebih aktif, memberikan pengayaan dan remedial, serta menjaga komunikasi dengan orang tua untuk memantau kesulitan belajar peserta didik di rumah.
\end{abstract}

Kata kunci: IPA, masalah belajar, sekolah dasar

Social, Humanities, and Education Studies (SHEs): Conference Series https://jurnal.uns.ac.id/shes

p-ISSN 2620-9284

e-ISSN 2620-9292 


\section{PENDAHULUAN}

Pada awal tahun 2020 muncul virus corona baru yang diberi nama SARS Cov-2 yang menyerang manusia melalui saluran pernapasan. Penyakit tersebut yang kemudian dikenal dengan istilah covid-19. Pemerintah Indonesia mengeluarkan kebijakan untuk memutus rantai penyebaran covid-19 yaitu dengan physical distancing atau menjaga jarak dengan orang sekitarnya, menjauhi aktivitas dalam segala bentuk kerumunan, dan menghindari adanya pertemuan yang melibatkan banyak orang (Simanjuntak dkk, 2020). Himbauan physical distancing dan lock down di beberapa wilayah diatur dalam PP Nomor 21 Tahun 2020.

Pendidikan di Indonesia menjadi salah satu bidang yang terdampak akibat pandemi covid-19. Kementerian Pendidikan Indonesia juga mengeluarkan Surat Edaran Nomor 4 Tahun 2020 pada tanggal 24 Maret 2020 tentang Pelaksanaan Kebijakan Pendidikan Dalam Masa Darurat Penyebaran COVID, dalam Surat Edaran tersebut dijelaskan bahwa proses kegiatan belajar mengajar dilaksanakan dengan menggunakan sistem dalam jaringan (daring). Selama pandemi peserta didik dituntut untuk beradaptasi dalam melakukan kegiatan belajar di rumah masing-masing. Hal tersebut mengakibatkan munculnya kesulitan belajar akibat kebiasaan belajar siswa yang berubah dari luring ke daring, khususnya dalam pembelajaran Ilmu Pengetahuan Alam (IPA)

Pembelajaran IPA merupakan pembelajaran aktif, peserta didik dilibatkan dalam pencarian dan pengembangan pengetahuan. Peserta didik diharapkan aktif dalam mencari dan menemukan konsep, mampu menganalisis suatu masalah, aktif dalam diskusi, berani menyampaikan gagasan, mampu mendengarkan dan menerima gagasan dari orang lain, mampu menuliskan hasil kerja sebagai laporan, serta mampu menyampaikan hasil kerja. Pembelajaran IPA di SD hendaknya membuka kesempatan untuk memupuk rasa ingin tahu peserta didik secara ilmiah (Awang, 2015). Pendidikan IPA di SD hendaknya sudah menanamkan prinsip-prinsip IPA yang bisa diaplikasikan dalam kehidupan sehari-hari peserta didik. Hal ini akan membantu mereka dalam mengembangkan kemampuan bertanya dan mencari jawaban atas fenomena alam. Pendidikan IPA di sekolah dasar diharapkan dapat menjadi wahana bagi peserta didik untuk mempelajari diri sendiri dan alam sekitar, serta prospek pengembangan lebih lanjut dalam menerapkannya dalam kehidupannya sehari-hari (Andriana dkk, 2020). Pembelajaran IPA merupakan suatu hal yang penting. Namun, tidak jarang permasalahan-permasalahan dalam pembelajaran IPA terjadi, permasalahan belajar siswa dapat terjadi dari berbagai aspek meliputi masalah pribadi, masalah penyesuaian sosial, dan kesulitan belajar.

Kesulitan belajar adalah keadaan dimana siswa tidak mampu melaksanakan proses pembelajaran sebagaimana mestinya (Dalyono, 2015). Kesulitan belajar adalah suatu situasi dimana anak didik tidak dapat belajar secara wajar, disebabkan adanya ancaman, hambatan atau gangguan dalam belajar. Hambatan itu menyebabkan orang tersebut mengalami kegagalan atau setidak-tidaknya kurang berhasil dalam mencapai tujuan belajar (Minarti dkk, 2015). Kesulitan belajar dapat disebabkan oleh faktor internal maupun eksternal. Faktor internal berupa kondisi tubuh, psikologis, motivasi, minat, sikap, dan kebiasaan belajar. Sedangkan faktor eksternal berupa fasilitas belajar, perhatian orang tua, kondisi lingkungan, serta cara guru mengajar. Selama pembelajaran daring, kesulitan belajar yang dialami oleh peserta didik meningkat terutama dalam pembelajaran IPA. Hal tersebut diakibatkan karena peserta didik harus mengubah kebiasaan belajar mereka menjadi pembelajaran daring secara mendadak dengan minimnya persiapan.

Berdasarkan uraian tersebut, maka dilakukan identifikasi kesulitan belajar IPA selama pandemi covid-19 di kelas V SDN Peterongan. Adapun tujuan penelitian ini yaitu untuk mendapatkan informasi apa saja kesulitan yang dihadapi peserta didik dalam melaksanakan pembelajaran IPA secara daring selama masa pandemi 
sehingga guru dapat menemukan solusi supaya pembelajaran IPA yang dilaksanakan selama masa pandemi ini dapat berjalan dan memberikan hasil belajar yang maksimal. Penelitian yang relevan dengan penelitian ini dilakukan oleh Encep Andriana dkk pada tahun 2020 dengan judul "Pembelajaran IPA di SD pada Masa Covid 19". Kesimpulan dari penelitian ini adalah pelaksanaan kegiatan belajar mengajar dengan sistem daring yang dilaksanakan di rumah melalui berbagai platform aplikasi yang tersedia seperti Zoom, Google Meet, Google Classroom harus dapat dioptimalkan. Untuk daerah yang termasuk kedalam zona kuning maupun zona hijau dapat dilakukan home visit dan tetap mengikuti protokol kesehatan.

\section{METODE}

Penelitian ini menggunakan metode penelitian deskriptif kualitatif dengan pendekatan fenomenologi. Data penelitian diperoleh langsung dari peneliti sekaligus guru kelas $\mathrm{V}$, peserta didik kelas $\mathrm{V}$, dan orang tua peserta didik kelas $\mathrm{V}$ SDN Peterongan. Teknik pengumpulan data diperlukan oleh peneliti untuk memperoleh data di lapangan. Menurut Sugiyono (2014), teknik pengumpulan data merupakan langkah yang paling strategis dalam penelitian, karena tujuan utama dari penelitian adalah mendapatkan data. Adapun teknik pengumpulan data yang digunakan dalam penelitian ini adalah dengan menggunakan angket, wawancara, dan dokumentasi hasil pekerjaan peserta didik. Keabsahan data merupakan bentuk batasan yang berkaitan dengan suatu kepastian yang dapat dicapai dengan proses pengumpulan data yang tepat, salah satu caranya adalah triangulangsi, yaitu teknik pemeriksaan keabsahan data yang memanfaatkan sesuatu yang lain untuk keperluan atau sebagai pembanding terhadap data yang telah ada (Sugiyono, 2017). Analisis data diperlukan untuk menyusun secara sistematis data yang diperoleh dari hasil angket, wawancara dengan cara mengelompokkannya dalam suatu bentuk yang mudah dibaca dan dapat diinterpretasi sehingga dapat membuat kesimpulan dari penelitian. Analisis data dalam penelitian ini menggunakan model interatif Miles dan Huberman meliputi pengumpulan data, reduksi data, penyajian data, dan kesimpulan data.

\section{HASIL DAN PEMBAHASAN}

Penelitian dilaksanakan di SDN Peterongan Kota Semarang pada 30 peserta didik kelas V. Data diperoleh menggunakan angket, wawancara, dan dokumentasi hasil pekerjaan peserta didik. Angket dibagikan kepada 30 peserta didik, sedangkan wawancara dilakukan kepada 3 orang tua dan 3 peserta didik. Hasil penelitian dan pembahasan adalah sebagai berikut.

a. Kurangnya Minat dan Motivasi Siswa

Selama pandemi ini SDN Peterongan mengalihkan pembelajaran menjadi metode daring. Pembelajaran dengan metode daring ini dilaksanakan di rumah dengan memanfaatkan alat komunikasi berupa handphone melalui aplikasi whatsapp, peserta didik mengerjakan tugas pada buku yang dimiliki siswa dan dibantu dengan pengawasan orang tua di rumah. Seringkali juga guru menggunakan aplikasi tatap muka seperti google meet untuk berinteraksi dengan peserta didik. Hasil angket yang diberikan kepada peserta didik disajikan pada tabel berikut. 
Tabel 1. Hasil angket minat dan motivasi peserta didik selama pembelajaran

\begin{tabular}{lc}
\multicolumn{1}{c}{ daring } & \multicolumn{1}{c}{ Pernyataan } \\
\hline $\begin{array}{l}\text { Saya merasa senang dengan dilaksanakannya } \\
\text { pembelajaran daring }\end{array}$ & $30 \%$ \\
$\begin{array}{l}\text { Saya selalu mengikuti pembelajaran daring } \\
\text { Saya selalu didampingi orang tua saat pembelajaran } \\
\text { daring }\end{array}$ & $43 \%$ \\
$\begin{array}{l}\text { Saya merasa pembelajaran IPA cocok dengan metode } \\
\text { daring }\end{array}$ & $50 \%$ \\
\hline
\end{tabular}

Tabel 1. menunjukkan hasil angket ditemukan bahwa 30\% peserta didik merasa senang dengan dilaksanakannya pembelajaran daring, itu artinya $70 \%$ peserta didik atau 21 dari 30 peserta didik tidak merasa senang dengan pembelajaran daring. Jika sudah tidak senang maka peserta didik akan berkurang minat dan motivasi belajarnya. Hasil angket juga menunjukkan bahwa $43 \%$ peserta didik selalu mengikuti pembelajaran daring, artinya 53\% peserta didik atau 17 dari 30 peserta didik tidak selalu mengikuti pembelajaran daring. Jika sudah tidak mengikuti pembelajaran daring maka peserta didik tidak akan menerima pembelajaran dari guru. Hasil angket berikutnya menunjukkan bahwa $50 \%$ peserta didik atau 15 dari 30 peserta didik selalu didampingi orang tua saat pembelajaran daring. Hasil angket yang terakhir yaitu $20 \%$ peserta didik merasa pembelajaran IPA cocok dengan metode daring, artinya $80 \%$ peserta didik atau 24 dari 30 peserta didik merasa pembelajaran IPA tidak cocok dengan metode daring. Dari tabel tersebut menunjukkan bahwa minat dan motivasi peserta didik berkurang selama pandemi ini. Dalam hal belajar siswa akan berhasil jika dalam dirinya sendiri ada kemauan untuk belajar dan keinginan atau dorongan untuk belajar, karena dengan peningkatan motivasi belajar maka siswa akan tergerak, terarahkan sikap dan perilaku siswa dalam belajar IPA (Hamdu \& Agustina, 2011). Dari hasil wawancara dengan orang tua peserta didik, pembelajaran dengan metode daring yang dilakukan melalui whatsapp tetap memberatkan orang tua peserta didik, terlebih bagi peserta didik yang tidak memiliki alat komunikasi akan tertinggal. Kondisi daerah yang terkendala koneksi internet juga akan mengalami kesulitan dalam mengikuti pembelajaran daring. Pada dasarnya dalam pembelajaran IPA di Sekolah Dasar perlu dilakukan pembelajaran dengan metode luring dikarenakan pembelajaran IPA membutuhkan percobaan yang hanya bisa dilakukan melalui pembelajaran langsung dengan adanya panduan dan bimbingan dari guru (Andriana dkk, 2020).

b. Kesulitan Memahami Konsep

Berikut ini adalah data yang diperoleh dari hasil angket dan hasil pekerjaan peserta didik dalam soal penilaian akhir semester 1 mengenai kesulitan memahami konsep dalam soal IPA.

Tabel 2. Hasil angket kesulitan memahami konsep IPA

\begin{tabular}{lc}
\hline \multicolumn{1}{c}{ Pernyataan } & Persentase \\
\hline Saya memahami konsep peredaran darah manusia & $27 \%$ \\
Saya memahami konsep fotosintesis pada tumbuhan & $40 \%$ \\
hijau & \\
$\begin{array}{l}\text { Saya memahami konsep hubungan sifat benda dan } \\
\text { bahan penyusunnya }\end{array}$ & $23 \%$ \\
\hline
\end{tabular}


Tabel 2. menunjukkan bahwa konsep peredaran darah manusia hanya dipahami oleh $27 \%$ peserta didik, artinya sebanyak $73 \%$ peserta didik atau 22 dari 30 peserta didik tidak memahami konsep tersebut. Pada konsep fotosintesis hanya dipahami oleh $40 \%$ peserta didik yang artinya sebanyak $60 \%$ atau 18 dari 30 peserta didik tidak memahami konsep tersebut. Pada konsep sifat benda dan bahan pesnyusunnya hanya dipahami oleh $23 \%$ peserta didik yang artinya sebanyak $77 \%$ atau 19 dari 30 peserta didik tidak memahami konsep tersebut. Hasil pekerjaan peserta didik menunjukkan bahwa peserta didik mengalami kesulitan dalam menganalisis urutan peredaran darah manusia dan menjelaskan perubahan sifat benda. Aspek pemecahan masalah ini terlihat ketika siswa tidak melanjutkan pekerjaanya, ketika memasuki suatu konsep baru. Dapat dikatakan pula bahwa banyak siswa yang tidak mampu mengkombinasikan antara konsep dengan keterampilan sehingga siswa tidak dapat melanjutkan pekerjaannya (Fauziyah dkk, 2020). Karena keabstrakan konsepnya, maka mempelajari IPA memerlukan kegiatan berfikir yang sangat tinggi sehinnga banyak siswa yang menganggap pelajaran IPA sulit, memusingkan dan membosankan untuk dipelajari (Wahyuni, 2018). Padahal mata pelajaran IPA juga tentunya tidak lepas dari praktikum. Praktikum yang biasanya dilakukan di sekolah bersama guru, alat dan bahan yang biasanya sudah disediakan dilaboratorium IPA, hal itu tidak dapat dirasakan lagi oleh para peserta didik, dan peserta didik juga harus melakukan praktikum mandiri dirumah dengan alat dan bahan seadanya (Salsabila, 2020). Pembelajaran IPA menekankan pada pengalaman langsung bagi siswa untuk mengembangkan potensinya, sehingga siswa mampu memahami alam sekitar melalui proses mencari tahu yang akan membantu siswa dalam memperoleh pengalaman tentang alam sekitar. Tetapi dengan adanya pandemi, pembelajaran IPA harus dilakukan secara daring atau dilakukan mandiri oleh siswa (Handayani \& Jumadi, 2021). Dengan demikian hal ini menjadikan peserta didik malas serta susah dalam melakukan belajar. Keadaan seperti ini yang membuat siswa menjadi sulit untuk memahami materi yang diberikan oleh guru, terutama pada materi IPA, yang mana mengaharuskan siswa untuk mengamati, memahami, serta menyimpulkan sendiri materi yang sedang dipelajari.

c. Faktor yang menyebabkan kesulitan belajar IPA

Ada dua faktor yang menyebabkan kesulitan belajar yang dihadapi peserta didik selama belajar di rumah, yaitu faktor internal dan eksternal. Hasil angket dan wawancara antara peserta didik dan orang tua, serta hasil observasi peneliti menyatakan faktor internal yang menjadi penyebab utama munculnya kesulitan belajar IPA di rumah adalah rendahnya minat dan motivasi peserta didik dalam pembelajaran IPA sehingga memberikan kesan bahwa IPA adalah pelajaran yang sulit. Faktor eksternal yang menjadi penyebab terbesar munculnya kesulitan belajar IPA di rumah adalah kurangnya perhatian orang tua dalam mendampingi dan membimbing peserta didik saat belajar IPA di rumah, kurangnya fasilitas pembelajaran daring yang dimiliki peserta didik, dan minimnya kemampuan peserta didik dalam menggunakan aplikasi pembelajaran daring seperti google meet juga menjadi salah satu faktor penyebab permasalahan belajar terjadi. Media dan model pembelajaran yang digunakan oleh guru yang kurang maksimal juga membuat peserta didik kurang tertarik dalam mempelajari materi di rumah selama pandemi.

d. Solusi untuk mengatasi kesulitan belajar IPA

Solusi yang dapat dilakukan untuk meminimalisir kesulitan belajar IPA selama masa pandemi ini antara lain meningkatkan minat dan motivasi peserta didik dengan memilih metode dan media pembelajaran yang lebih menarik dan membuat peserta didik menjadi lebih aktif dalam pembelajaran, misalnya dengan menerapkan model pembelajaran PBL, PjBL, discovery learning, dll, maupun menggunakan youtube dan lab virtual sebagai media pembelajaran, sehingga peserta didik tetap 
mendapatkan pengalaman belajar walaupun pembelajaran dilakukan di rumah. Memberikan pengayaan dan remedial kepada peserta didik juga dapat dilakukan untuk memberikan penguatan materi. Selanjutnya, menjaga komunikasi dengan orang tua peserta didik untuk memantau kesulitan belajar peserta didik di rumah merupakan hal yang paling penting untuk dilakukan oleh guru selama pembelajaran daring ini.

\section{SIMPULAN}

Berdasarkan penelitian yang telah dilakukan maka peneliti menyimpulkan bahwa kesulitan-kesulitan belajar IPA yang dialami peserta didik yaitu berkurangnya minat dan motivasi belajar dikarenakan terlalu bosan setiap hari di rumah melakukan pembelajaran melalui handphone. Pembelajaran dengan metode daring yang dilakukan melalui whatsapp juga memberatkan orang tua peserta didik, terlebih bagi peserta didik yang tidak memiliki alat komunikasi akan tertinggal materi. Kondisi daerah yang terkendala koneksi internet juga akan mengalami kesulitan dalam mengikuti pembelajaran daring. Dari segi materi pelajaran IPA, peserta didik mengalami kesulitan dalam menganalisis urutan peredaran darah manusia, menganalisis proses fotosintesis, dan menjelaskan perubahan sifat benda. Peserta didik merasa kesulitan memahami materi dikarenakan materi IPA jika diajarkan melalui metode daring akan terasa seperti abstrak, padahal IPA tidak lepas dari praktikum, alat peraga, dan observasi lingkungan dengan bimbingan guru. Praktikum yang biasanya dilakukan di sekolah bersama guru, alat dan bahan yang biasanya sudah disediakan di laboratorium IPA tidak dapat dirasakan lagi oleh para peserta didik, dan peserta didik juga harus melakukan praktikum mandiri dirumah dengan alat dan bahan seadanya.

\section{DAFTAR PUSTAKA}

Andriana, E. Ramadayanti, S., Noviyanti, T. E. 2020. Pembelajaran IPA di SD Pada Masa Covid-19. Prosiding Seminar Nasional Pendidikan FKIP Universitas Sultan Ageng Tirtayasa. 3 (1): 409-413

Awang, I. S., 2015. Kesulitan Belajar IPA Peserta Didik Sekolah Dasar. Jurnal Vox Edukasi. $6(2): 108-122$

Dalyono, M. 2015. Psikologi Pendidikan. Jakarta: Rineka Cipta

Fauziyah, I. B., Sukarno, \& Sriyanto, M. I. 2020. Identifikasi Kesulitan Belajar Matematika di Rumah Selama Pandemi Covid-19 pada Siswa Kelas IV Sekolah Dasar. Jurnal Pendidikan Dasar. 9 (1): 25-30

Hamdu, G., Agustina, L. 2011. Pengaruh Motivasi Belajar Siswa Terhadap Prestasi belajar IPA di Sekolah Dasar. Jurnal Penelitian Pendidikan. 12 (1): 81-86

Handayani, N. A., Jumadi. 2021. Analisis Pembelajaran IPA Secara Daring pada Masa Pandemi Covid-19. Jurnal Pendidikan Sains Indonesia. 9 (2): 217-233

JDHI BPK RI. Pembatasan Sosial Berskala Besar dalam Rangka Percepatan Penanganan Corona Virus Disease 2019 (COVID-19). 2020

Minarti, Pitoewas, B., \& Yanzi, H. 2015. Faktor-faktor Penyebab Kesulitan Belajar Siswa dalam Mengikuti Pelaksanaan Belajar Tuntas. Jurnal Kultur Demokrasi. 3 (2)

Salsabila, F. 2020. Analisis Motivasi Belajar IPA Peserta Didik pada Pembelajaran ELearning Class Selama Pandemi Covid-19. Skripsi

Simanjutak, D. S., Ritonga M. N., \& Harahap M S. 2020. Analisis Kesulitan Belajar Siswa Melaksanakan Pembelajaran Secara Daring Selama Masa Pandemi Covid-19. Mathematic education journal. 3 (3): 142-145

Sugiyono. 2014. Memahami Penelitian Kualitatif. Bandung: Alfabeta

Sugiyono. 2017. Metode Penelitian Kombinasi (Mixed Methods). Bandung: Alfabeta

Wahyuni. 2018. Analisis Kesulitan Belajar Siswa Pada Mata Pelajaran IPA di Kelas VII SMP negeri 4 Terbanggi besar. Jurnal Sains dan Teknologi. 1 (1): 19-26 